\title{
Participation of Farm Women in Agricultural Operations in Srikakulam District of Andhra Pradesh, India
}

\author{
D. Chinnam Naidu, K. Bhagya Lakshmi* and G. S. Roy \\ Krishi Vigyan Kendra, Amadalavalasa, Srikakulam District, Andhra Pradesh \\ Achraya N.G Ranga Agricultural University, India \\ *Corresponding author
}

\section{Keywords}

Participation of farm women,

Capacity building, gender main streaming,

Extension reforms

\section{Article Info}

Accepted:

15 May 2020

Available Online:

10 June 2020

\begin{abstract}
A B S T R A C T
Women play a significant and crucial role not only in agriculture but also in agricultural allied activities. Over the years, there is a gradual realization of the key role of women in agriculture development and their vital contribution in the field of agriculture, food security, horticulture, livestock management, processing, nutrition, sericulture, fisheries, and other allied sectors. As cultivators, agricultural labourers, artisans and house wives they constitute sizable section of work force. Hence, an indepth appraisal of role played by the women in agricultural operations need to be made by the extension agencies to plan extension activities for capacity building of the farm women and gender main streaming under extension reforms. By keeping this in view an attempt was made by KrishiVigyanKendra, Amadalavalasa to study the Participation of Farm Women in Agricultural Activities in Srikakulam district of Andhra Pradesh. The total sample size consists of 120 farm women selected from six mandals of Srikakulam district namely, Amadalavalasa, G sigadam, polaki, Kotturu, Narasannapeta and Hiramandalam for the study. The primary data were collected from the respondents through survey and personal interview method. There results of the study revealed that the higher percentage $(67.50 \%)$ of the farm women were medium extent of participation in agricultural activities.
\end{abstract}

\section{Introduction}

Women produce over fifty per cent of the world's food (The Food and Agriculture Organization, 2011), is an indicator of the integral part played by the women in agriculture allied sectors. Women are engaged in various on farm and off farm activities, which makes their role a multi-dimensional one. Women make essential contributions to agriculture and rural economies in all developing countries. Their roles vary considerably between and within regions are changing rapidly in many parts of the world, where economic and social forces are transforming the agricultural sector. Agriculture needs manpower, if the man power split into gender wise, amazing fact is that the women contribution is greater or equal to men.(SarithaSingh .Ku, 2015). 
Women play a significant role not only in agriculture but also in livestock production, horticulture, agro forestry, fisheries and household activities. The contributions made by the women are not recognized since ages. Rathod, et al., (2011) opined that though women play a significant role in dairy farming their control over livestock and its products is very minimal.

Despite of their substantial contributions, they remained as invisible hands. There has been a tendency among extension professionals and policy makers to see 'Men' as farmers and farmer's wives. Although women are involved in various agricultural operations, policy planners tend to highlight their 'supportive role' rather than their productive role .With growing realization of immense contributions of women in agriculture many research studies have been initiated to study the women's participation in agriculture. But in-depth analysis of the actual participation of women in farm operations is required to plan and implement extension activities for gender mainstreaming in agriculture. By keeping these inadequacies in view, the present investigation was made by Krishi Vigyan Kendra, Amadalavalasa to study the extent of participation of farm women in agricultural operations in Srikakulam district of Andhra Pradesh.

\section{Materials and Methods}

The present study was carried out during 2018-19 in the Srikakulam district of Andhra Pradesh. Sixmandals out of 38 mandals of Srikakulam district namely, Amadalavalasa, G Sigadam, Polaki, Kotturu, Narasannapeta and Hiramandalam were selected purposively. From each of these mandals one village was selected purposively asthese villages are the adopted villages of KrishiVigyan Kendra Amadalavalasa. Thus, six village's namely Nimmatorlawada, Chettupodilam, K.P
Valasa, Nadagam, Sirusuwada and Ambavalli were selected for the study. A total number of 120 farm women were selected as sample, comprised of 20 farm women from each village. The data pertaining to the variables, the objectives were collected with the help of structured interview schedule developed for the study. The data were analyzed by using frequency, percentage and Mean score.

\section{Results and Discussion}

\section{Extent of participation of farm women in agricultural operations}

It is evident from the table 1 that the extent of participation by the majority of the farm women in agricultural operations was medium $(67.50 \%)$,followed by high $(17.50 \%)$ and low $(15.00 \%)$. The findings were inconformity with conclusions of Bhairve (2013) and Kajal Kumari Chauhan et al., (2019)which details the extent of women's participation in agricultural activities.

It can be seen from the table. 2 that among various agricultural operations, 'Sowing of seeds and transplanting' was ranked I with highest mean score (2.52). It can be concluded from the results that the extent of participation by the farm women was high in sowing and transplanting. Similar results were reported by (Gowdappa, et al., 20120) and (Yadav, et al., 2019). This is due to the fact that women predominantly participate in sowing and transplanting activities which are relatively lighter in nature, less intensive, monotonous and repetitive in nature. Sowing and transplanting needs frequent bending which results drudgery among women. Hence, there is an immense need for building capacities of farm women by training, facilitation and skill up gradation for ensuring the usage of cost effective drudgery reduction technologies like easy planters seed dibblers and drum seeders. 
Table.1 Distribution of farm women according to extent of participation in different agricultural operations $(\mathrm{N}=120)$

\begin{tabular}{|l|l|l|l|}
\hline S.No & Categories & Frequency & Percentage \\
\hline 1. & Low $(1$ to 8 score $)$ & 18 & 15.00 \\
\hline 2. & Medium $(9-16$ score $)$ & 81 & 67.50 \\
\hline 3. & High $(17-24$ score $)$ & 21 & 17.50 \\
\hline & Total & 120 & 100.00 \\
\hline
\end{tabular}

Table.2 Distribution of farm women according to extent of participation in agricultural activities $\mathrm{N}=120$

\begin{tabular}{|l|l|l|l|l|l|l|l|l|l|}
\hline S.No & Area of activities & \multicolumn{3}{|c|}{ Frequency } & \multicolumn{3}{|c|}{ Percentage } & Mean & Rank \\
\cline { 3 - 8 } & & Regular & $\begin{array}{l}\text { Someti } \\
\text { mes }\end{array}$ & Never & Regular & $\begin{array}{l}\text { Some } \\
\text { times }\end{array}$ & Never & & \\
\hline $\mathbf{1}$ & Field preparation & 7 & 20 & 93 & 6 & 17 & 78 & 1.28 & IX \\
\hline $\mathbf{2}$ & Selection of seed & 25 & 45 & 50 & 21 & 38 & 42 & 1.79 & VI \\
\hline $\mathbf{3}$ & Seed treatment & 7 & 10 & 103 & 6 & 8 & 86 & 1.20 & XI \\
\hline $\mathbf{4}$ & $\begin{array}{l}\text { Sowing of seeds } \\
\text { and transplanting }\end{array}$ & 78 & 22 & 24 & 63 & 18 & 19 & 2.52 & I \\
\hline $\mathbf{5}$ & $\begin{array}{l}\text { Manure and fertilizer } \\
\text { application }\end{array}$ & 30 & 40 & 50 & 25 & 33 & 42 & 1.83 & V \\
\hline $\mathbf{6}$ & Irrigation & 3 & 15 & 102 & 3 & 13 & 85 & 1.18 & XII \\
\hline $\mathbf{7}$ & $\begin{array}{l}\text { Weeding and intercultural } \\
\text { operations }\end{array}$ & 70 & 30 & 19 & 59 & 25 & 16 & 2.41 & III \\
\hline $\mathbf{8}$ & Plant protection measures & 27 & 28 & 65 & 23 & 23 & 54 & 1.68 & VII \\
\hline $\mathbf{9}$ & Harvesting operations & 73 & 25 & 22 & 61 & 21 & 18 & 2.43 & II \\
\hline $\mathbf{1 0}$ & Winnowing & 32 & 38 & 50 & 27 & 32 & 42 & 1.85 & IV \\
\hline $\mathbf{1 1}$ & Storage & 6 & 23 & 91 & 5 & 19 & 76 & 1.29 & VIII \\
\hline $\mathbf{1 2}$ & Marketing & 9 & 14 & 97 & 8 & 12 & 81 & 1.27 & X \\
\hline
\end{tabular}

It is observed from the results that farm women's participation in 'Harvesting' ranked second in agricultural operations with the mean score 2.43. This may be due majority of farm women participate in cutting and drying of the agricultural produce.

Hence, it is the responsibility of the extension agencies to promote the usage of improved sickles to reduce the strain and fatigue experienced by the farm women during harvesting. The table no. 2 revealed that 'Weeding and intercultural operations' was the $3^{\text {rd }}$ agricultural operation which was predominantly done by the farm women with
2.41 mean score. Weeding is another monotonous activity which requires continuous bending and squatting. Hence, facilitate women to use drudgery reduction equipment such as CRIDA wheel hoe and cycle weeders. Winnowing (1.85 mean score)) and Manure and fertilizer application (1.83 mean score) were ranked IV and V respectively in participation by farm women.

The findings are inconformity with the results reported by (Yama S, et al., 2019). A considerable participation was observed by farm women in seed selection (mean score 1.79), Plant protection (mean score 1.68), 
Storage (mean score 1.29), Field preparatory operations (mean score 1.27), marketing (mean score 1.27) seed treatment (mean score 1.20) and Irrigation (mean score 1.18) respectively. Hence, the extent of participation of farm women in various operations in a particular region need to studied critically by the extension agencies to implement gender specific strategies in agriculture and allied sectors.

The study revealed that farm women participate to a greater extent in sowing and transplanting, harvesting operations, weeding and inter cultivation. Along with these activities, a substantial participation by the farm women were observed in seed selection, plant protection, storage, field preparatory operations, marketing, seed treatment and irrigation respectively. Hence, it is necessary to consider the extent of participation by women as well as men, while planning and implementing extension reforms such as gender mainstreaming, Bottom up planning, Women empowerment, Women led Extension, Farm mechanization and drudgery reduction.

\section{References}

Bhairve.V (2013)A study on women's participation and decision making pattern in agriculture activities in Sehore district of Madhya Pradesh. M.Sc. (Ag.)Thesis (unpublished) JNKVV, Jabalpur.

Food and Agriculture Organization (2011) Women in Agriculture; closing the gender gap for development: In the state of food and Agriculture, FAO, Rome, Italy.

Goudappa1.S .B,Surekha .S and Reddy.B.S(2012)Participation of Farm Women in Decision-Making Process on Agricultural Operations in Yadgir District of Karnataka, Indian Research Journal of Extension Education Special Issue (I) :138-141.

KajalKumariChauhan ,Pande.A. K and LalitaNargawe (2019) Participation of Farm Women in Agricultural Activities in Tikamgarh District (M.P.) Indian Journal of Extension Education 55( 3): 147-149.

Rathod. P.K, NikamT.R ,Sariput.L, Rajeshwari.SHatey. A 2011 Participation of rural women in dairy farming in Karnataka. Indian journal of Extension Education; 11 (2): 31-36.

SarithaSingh. $\mathrm{Ku} \quad$ (2015)A study on involvement of farm women in agricultural activities in Gwalior district of Madhya Pradesh.Ph.D(Ag) Thesis (unpublished), RVSKVV, Gwalior.

Tharani.G, Akther $\quad$ M.S.Rand Nanthakumaran.A 2016 Assessment of Women Participation in Agriculture in Vavuniya District, Sri Lanka. Int. J. Soc. Sc. Manage 3 (3): 159-162.

Yadav.S, Sharam. N.K, Kumar .V, Mishra .P and Choudhary.S(2018) Role of Rural Women in Agriculture Activities in Jaipur District of Rajasthan, India. Int. J. Curr. Microbiol. App. Sci 7(2): 3549-3555.

\section{How to cite this article:}

Chinnam Naidu. D., K. Bhagya Lakshmi and Roy. G. S. 2020. Participation of Farm Women in Agricultural Operations in Srikakulam District of Andhra Pradesh, India. Int.J.Curr.Microbiol.App.Sci. 9(06): 500-503. doi: https://doi.org/10.20546/ijcmas.2020.906.065 